\title{
DETERMINANT OF CAPITAL STRUCTURE : COAL AND NON COAL MINING INDUSTRY ON THE INDONESIA STOCK EXCHANGE
}

\author{
Triska Dewi Pramitasari
}

Universitas Abdurachman Saleh Situbondo, triska_dewi@unars.ac.id

\begin{abstract}
ABSTRAK
Penelitian ini dilakukan untuk menganalisis pengaruh biaya hutang, kebijakan dividen, profitabilitas, ukuran perusahaan, risiko bisnis, dan pertumbuhan perusahaan terhadap struktur modal industri pertambangan batubara dan non batubara di Bursa Efek Indonesia periode 2015-2019, dan terhadap menganalisis perbedaan pengaruh keenam determinan struktur modal pada dua sub sektor industri yang diteliti. Berdasarkan metode purposive sampling diperoleh 19 perusahaan tambang batubara dan 17 perusahaan non tambang batubara sebagai sampel penelitian. Metode analisis yang digunakan adalah analisis regresi linier berganda dan uji Chow. Hasil analisis menunjukkan bahwa secara simultan cost of debt, kebijakan dividen, profitabilitas, ukuran perusahaan, risiko bisnis, dan pertumbuhan perusahaan berpengaruh signifikan terhadap struktur modal sub sektor batubara, namun tidak berpengaruh signifikan terhadap sub sektor non batubara. Secara parsial, keenam variabel tersebut memiliki pengaruh yang bervariasi pada dua sub sektor industri yang diteliti. Hasil Chow test menunjukkan adanya perbedaan pengaruh biaya hutang, kebijakan dividen, profitabilitas, ukuran perusahaan, risiko bisnis, dan pertumbuhan perusahaan terhadap keputusan struktur modal pada sub sektor batubara dan non batubara. Batasan penelitian ini hanya mengkaji kestabilan parameter dalam model regresi tanpa menginformasikan seberapa besar perubahan atau perbedaannya. Hasil penelitian ini bermanfaat bagi perusahaan pertambangan dan akademisi. Batasan penelitian ini hanya mengkaji kestabilan parameter dalam model regresi tanpa menginformasikan seberapa besar perubahan atau perbedaannya. Hasil penelitian ini bermanfaat bagi perusahaan pertambangan dan akademisi. Batasan penelitian ini hanya mengkaji kestabilan parameter dalam model regresi tanpa menginformasikan seberapa besar perubahan atau perbedaannya. Hasil penelitian ini bermanfaat bagi perusahaan pertambangan dan akademisi.
\end{abstract}

Kata kunci: risiko bisnis, struktur modal, ukuran perusahaan, biaya hutang, kebijakan dividen

\begin{abstract}
This research was conducted to analyze the effect of debt costs, dividend policy, profitability, company size, business risk, and company growth on the capital structure of coal and non-coal mining industry on the Indonesia Stock Exchange 2015-2019 period, and to analyze the differences in the effect sixth determinant of capital structure in the two industrial subsectors studied. Based on purposive sampling method was obtained 19 coal mining companies and 17 non-coal mining companies as the research sample. The analytical method used is multiple linear regression analysis and Chow test. The analysis showed that simultaneously cost of debt, dividend policy, profitability, company size, business risk, and company growth has a significant effect on the capital structure of the coal sub-sector, but no significant effect on non-coal sub-sector. Partially, the sixth of these variables have varying effect in the two industrial subsectors studied. Chow test results indicate a difference in effect cost of debt, dividend policy, profitability, company size, business risk, and company growth on capital structure decisions in the coal and non-coal sub-sectors. The limitation of this research is only examines the
\end{abstract}


stability of the parameters in the regression model without informing how big a change or difference. The results of this study are beneficial to mining companies and academics.

Keywords: business risk, capital structure, company size, cost of debt, dividend policy

Naskah diterima : 03-02-2021 Naskah dipublikasikan: 31-03-2021

\section{INTRODUCTION}

One of the decisions that every company manager must face in relation to the continuity of the company's operations is a capital structure decision, namely financial decisions related to the composition of debt to equity to be used by the company. The capital structure decision determined by the company is basically built on the relationship between decisions in choosing the source of funds and the investment that must be chosen so that it is in line with the company's objectives, namely maximizing the welfare of shareholders which is reflected in the market value of the company's share price (Rahendra, 2010).

Capital structure decisions determined by each company not only affect the company's operational activities, but also will affect the risks that must be borne by the company itself. If the company increases leverage, then the company itself will increase the company's financial risk. Otherwise, companies must pay attention to tax issues when reducing the level of leverage, because some experts argue that excessive use of capital will reduce the level of profitability (Kartika, 2010). Therefore, each company must determine their capital structure decisions carefully with a variety of appropriate consideration.

The importance of capital structure decisions for the condition of the company, requires every company manager to know what factors need to be considered when making a capital structure decision. By knowing these factors, company managers will find it easier to make funding decisions, whether additional capital is needed for the development and growth of the company obtained from debt or have to publish new stock as an alternative.

Research that discusses factors affecting capital structure in various business sectors have been carried out. Lestari (2015) and Wardita and Astakoni (2018) in their study found that the pattern of capital structure decisions is determined by the characteristics of each company so that the factors that affect each company are different. While Sansoethan and Suryono (2016) and Ardiansyah and Srimindarti (2018) found the results that the type and characteristics of the company do not influence capital structure decisions. Some of these studies show different results. There are differences in the results making research on the determinants of capital structure in several different types or business sectors needs to be studied further. In this research, the object to be studied is coal and non-coal mining sub-sector companies.

As the mining industry in general, coal and non-coal mining sub-sector is an industrial subsector that has very complex risks. Risks faced by these two industrial subsectors very high and varied as physical risks, market risks related to changes in domestic and global selling prices, and financial risk the inevitable if it contains the results obtained mine considered uneconomical (speculative risks) while stage of exploration and exploitation carried out previously has been very expensive (migasreview.com). Besides, mining industry was also severely affected by the global economic conditions. 
Amid the declining global economic conditions due to the Covid-19 pandemic, funding issues become major problems that must be faced by the mining sector. Coal sub sector is a mining industry sub-sector most sensitive to fluctuations in the global economy. Since the beginning of the 2nd quarter of 2020 firms experienced the impact of falling commodity prices due to falling export and domestic demand due to oversupply market conditions. The fall in prices caused companies cash flow difficulties. In addition to weakening global coal demand, the Covid-19 pandemic situation as a national emergency which was then followed by Large-Scale Social Restrictions (PSBB) policies in several regions making use of electricity is reduced which ultimately affect the declining demand for coal use by PLN. Decreasing demand for PLN as well as other domestic industries affect the domestic coal absorption as well as the compliance percentage of domestic market obligation (DMO). Domestic coal demand has dropped dramatically which is around 110 million M / T which is much lower than that plan established by the Government namely amounting to 155 million M / T (APBIICMA, 2020). This condition has an impact on the decline in profits of most coal companies. Coal companies like PT. Adaro Energy and PT. Atlas Resources should net income declined by $60 \%$. Meanwhile, operating costs continue to increase. It also occurs in non-coal industry sub-sectors such as PT. Vale Indonesia Tbk where in the same year net income declined by $40 \%$ from the previous year. Meanwhile, operating expenses increased by 50\%. This resulted the cost of capital to be borne by the coal and non-coal industry sector is enormous. With such conditions, the coal and non-coal sub-sector must bear a higher risk especially financial risk.

The use of debt, especially long-term debt is very large it will facilitate coal sub-sector in financing all his business needs that require very large funds and considerable time to obtain the results of his efforts. However, the coal sub-sector must bear increasingly high financial risks when compared to non-coal sub-sectors that have less long-term debt. This is due to interest expense as well as loan principal installments that must be covered by coal sub-sector will increase. As a consequence, the possibility of a coal sub-sector company going bankrupt would certainly be even greater. Based on these conditions, then the core issues raised in this study is reviewing what is the funding decision or capital structure decisions in the coal and non-coal sub-sector influenced by the determinants of the same or different capital structure. The purpose of this study is to analyze the effect of cost of debt, dividend policy, profitability, company size, business risk and company growth on capital structure in the coal and non-coal mining sub-sector companies on the IDX for the 20152019 period, as well as analyzing the different effects of the six determinants of the capital structure in the two industrial subsectors studied.

\section{LITERATURE REVIEW AND HYPOTHESIS DEVELOPMENT \\ Research Framework}

The framework of the research can be seen in the following figure:

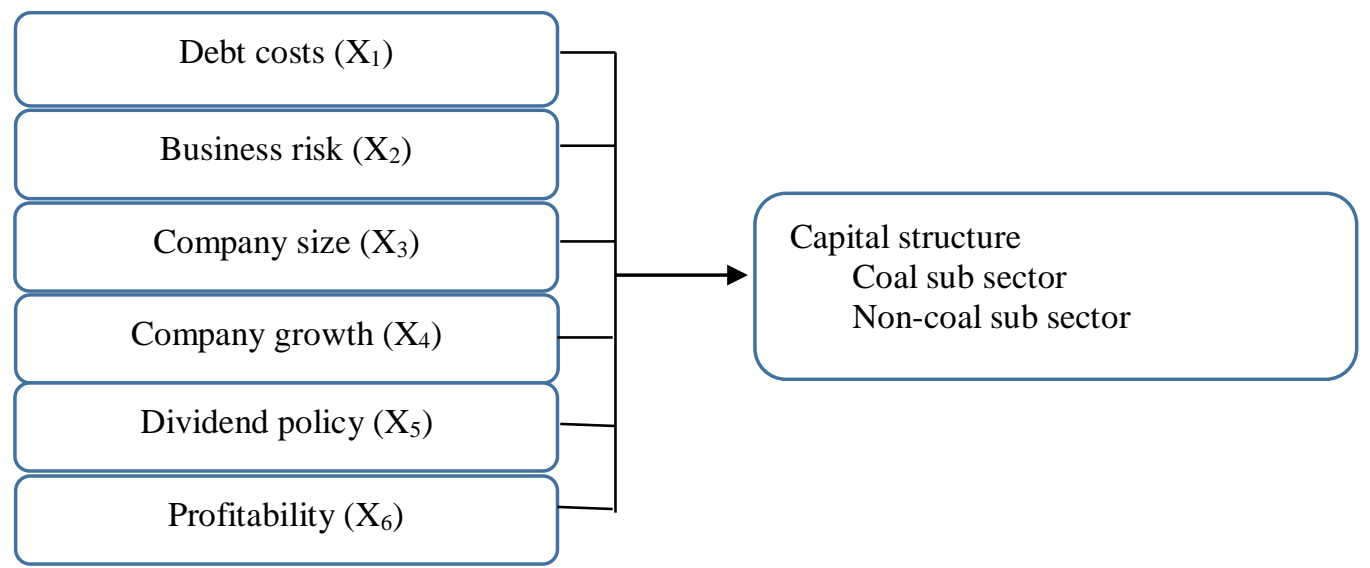

Figure 1. Research Framework 


\section{Pecking Order Theory}

Pecking-order assumes that company aims to maximize shareholder welfare. This theory was first introduced by Donaldson in 1961 while naming the pecking order theory conducted by Myers (2001). Donaldson (1961) observations of the behavior of the US company's capital structure. His observations show that companies that have high profits tend to use lower debt. Myers (2001) suggested the pecking-order theory, they establish a sequence of funding decisions where managers would first choose to use retained earnings, then debt and external equity as a last resort.

Pecking order theory explains why companies have an order of preference in choosing funding sources. This theory explains that companies prefer internal financing namely funding from the results of the company's operations in the form of retained earnings. When companies need external funding the company will publish the safest securities in advance namely by issuing bonds, followed by securities with option characteristics, and ultimately, if still not sufficient to issue new shares. So the order of using funding sources with reference to the pecking order theory are internal funds (internal funds), debt and equity.

\section{Trade Off Theory}

Trade off theory in capital structure balances benefits and sacrifices arising from the use of debt. As far as the benefits are greater, additional debt is still allowed. If the sacrifice due to the use of debt is already greater, then additional debt is not allowed. Brealey et.al (2008: 25) stated that high profits should have more debt service capacity and more taxable profit protected therefore it must provide a higher debt ratio. According to trade off theory that a company will achieve optimal value if all funding financed by debt or not using debt at all in financing company activities, so that company managers must be careful and precise in managing the company's capital composition.

\section{Agency Theory}

Agency theory discusses about agency relationship as a contract between company owners who use the services of others or agents in carrying out company activities. According to this approach, capital structure arranged in such a way to reduce conflict between various groups (Hanafi and Halim, 2012: 78). Management is expected to take the company's policies especially financial policy, can provide benefits for the owner of the company. When management decisions are detrimental to company owners, then it can trigger agency problems. This can be minimized with agency cost. Agency cost is the provision of appropriate incentives to managers as well as surveillance costs to prevent hazards. Agency relationship will lead to cost for the principal, such as spending on monitoring the agent's actions and expenditure on the existence of a contractual agreement with the agent.

\section{Capital Structure}

The capital structure shows the proportion of the use of debt to finance its investment, so that by knowing the capital structure, Investors can find a balance between risk and return on investment. Sartono (2001: 225) states that the capital structure is a balance of short-term debt, long-term debt, preferred stock and common stock. The decision to fulfill the need for funds includes various balances whether the company will use internal sources or external sources. Next financial managers are expected to apply alternative choice of the most appropriate sources of funding. Companies need to consider whether the funds are met from stock, debt, or a combination of both.

\section{Relationship between Cost of Debt and Capital Structure}

The cost of debt is one component in the cost of capital. According to Keown et al. (2000: 454), the cost of debt is the level that should be received from the investment to meet the implied rate of return creditors. The cost of debt arises because the company uses the funds from the loan. The amount of the company's debt costs is calculated based on simple interest rate that must be paid to 
creditors on new loans (Setyawati, 2018). The higher cost of debt will have a consequence the greater the probability of a decrease in company income. This resulted in the possibility of financial difficulties faced by the company will be even greater. Moeljadi (2006: 275) state that if the cost of debt is greater than the profitability of assets, then the addition of debt in the company's capital structure will have an unfavorable effect on its own capital profitability because it will create a greater financial obligation for the company. Therefore, companies that have high debt costs tends to reduce the proportion of debt expense. A decrease in the debt ratio has consequences for the company to use larger equity financing and conversely.

H1: Cost of debt has a significant negative effect on capital structure.

\section{Relationship between Business Risk and Capital Structure}

Gitman (2006: 498) define business risk as the risk of the company when unable to cover operational costs and is influenced by the stability of income and costs. Income stability is related to relative variability of the firm's sales revenue. A company with a stable level of demand and price will acquire stable sales revenue so that the level of business risk faced is getting lower. Cost stability relates to estimates relative to price component inputs such as labor costs. The more predictable and stable input prices component, the lower the level of corporate business risk (Sundjaja and Berlian, 2003). Business risk does not only vary from one industry to another, but also occurs between companies in one particular industry. Companies that have a high level of business risk tend to reduce and even avoid using debt in their financing. This is because the higher the business risk, the higher the possibility of financial distress faced by the company. This is in accordance with the tradeoff theory which explains that the higher the possibility of financial distress, the company will also bear high bankruptcy costs (Lestari, 2015). Conversely, the lower the level of business risk, the lower the likelihood of financial difficulties faced by the company so that the company will find it easier to use more debt. This is because companies that have a low level of business risk tend to have relatively stable earnings. A stable rate of earnings will affect the interest of creditors to provide larger loans. This theory is also supported by the results of research Lestari (2015) and Zulvia (2016).

H2: Business risk has a significant negative effect on capital structure.

\section{Relationship between Company Size and Capital Structure}

Company size shows the amount of assets owned by a company. Large companies are more likely to obtain loans and use large long-term funding than small companies (Moeljadi, 2006: 274). This is because large companies are relatively more stable and able to generate higher profits than small companies. In addition, company size is also considered an indicator that describes the level of risk for investors to invest in the company. The larger the company size, the greater the tendency to use external funds in funding. Conversely, small companies tend to use less external sources of funds or debt because the cash flow owned by the company tends to be less stable and the debt repayment guarantees provided tend to be smaller. Large companies have a very large need for funds and one alternative to fulfill the funds that can be used is external funds. Large companies can access the capital market and have more flexibility and ability to obtain funds because they can provide greater debt repayment guarantees than small companies (Yushinta and Suryandari, 2016). This theory is also supported by the results of research Yushinta and Suryandari (2016), Wardita and Astakoni (2018), Asteria (2018), Nugroho and Harmadi (2018), Astakoni and Utami (2019), and Salmah and Elmeira (2019).

H3: Firm size has a significant positive effect on capital structure.

\section{Relationship between Company Growth and Capital Structure}

Company growth is the growth of assets of a company which illustrates how the company invests the funds it has, and can be used as an indicator for future company development related to the total funding needs in the company (Moeljadi, 2006: 274). Companies with high growth rates must have sufficient capital to finance the company. If the company invests more than the amount of 
retained earnings owned by the company, it is possible that the loan amount from the creditor in the form of debt will increase (Jubaedah and Fadila, 2018). Therefore, companies that are growing rapidly must rely more on external capital. Brigham and Houston (2011: 43) state that companies that are growing rapidly must rely more on external capital. A high rate of asset growth implies a higher demand for external funds. This encourages fast-growing companies to use debt more to meet their funding needs. The pecking order theory states that if external funds are in funding, the first alternative for external funds to be chosen is to use debt first instead of having to issue new shares. Therefore, if the company's assets are experiencing growth while other factors are considered constant, the increase in assets will trigger an increase in the company's debt and otherwise. This theory is also supported by the results of research Lestari (2015), Jubaedah and Fadila (2018), Prihasti (2018), and Setiawati (2018).

H4: Company growth has a significant positive effect on capital structure.

\section{Relationship between Dividend Policy and Capital Structure}

Dividend is a form of profit expected by shareholders. The amount of dividend distribution will reduce the internal funds supply needed for the company's operations. Dividend policy is a company policy in determining how much profit to be paid to shareholders in the form of dividends and profits which will be reinvested in the company in the form of remaining profits (Brigham and Houston, 2011: 59). The company's policy to distribute dividends is a signal to shareholders of the value of a company. In a dividend signaling model developed by Bhattacharya in 1979, dividends are able to provide information about the value of a company that other media cannot fully convey such as annual reports, forecasts of earnings, or tests by assurance analysis. The distribution of dividends to shareholders makes the company have to reduce the cash inventory and the remaining profit which is reinvested into the company. In addition, a stable dividend policy requires companies to provide a certain amount of funds to be distributed to shareholders (Prihasti, 2018). As a result, there are fewer internal funds available within the company and require the company to obtain additional funds to carry out its operational activities. This will trigger the company to increase its debt level.

H5: Dividend policy has a significant positive effect on capital structure.

\section{Relationship between Profitability and Capital Structure}

Profitability can be defined as the net income from a series of company policies and operational decisions (Moeljadi, 2006: 73). Companies generally prefer the income they receive to be used as the main source of investment financing. Companies that are very profitable basically don't need debt to meet their funding needs. The high rate of return on investment allows the company to finance most of its funding needs through equity financing (Brigham and Houston, 2011: 43). This is consistent with the pecking order theory which explains that companies tend to prefer to use as many internal sources of funds as possible first rather than using debt when companies need funds for investment purposes. The higher the stock of funds to finance company operations and investment opportunities that come from internal sources of funds such as retained earnings, the smaller the debt level will be. On the other hand, companies that have a low level of profitability tend to carry out debt financing. This theory is also supported by the results of research Musabbihan and Purnawati (2018) and Wahyuni and Ardini (2017).

H6: Profitability has a significant negative effect on capital structure.

\section{RESEARCH METHODOLOGY}

The population in this study were all coal and non-coal mining companies listed on the Indonesia Stock Exchange during the 2015-2019 period. The sample selection in this study applies the purposive sampling method, namely the sampling method using several criteria. The data used in this study is secondary data in the form of corporate financial reports obtained from the 2015-2019 financial report database published by the IDX. The dependent variable in this study is the capital structure proxied by the debt ratio, while the independent variables include the cost of debt, dividend 
policy, profitability, company size, business risk, and company growth. Details of the identification and measurement of research variables are presented in Table 1.

Table 1. Identification and Measurement of Variables

\begin{tabular}{|c|c|c|}
\hline Variable & Symbol & Measurement \\
\hline Debt Ratio & $D E R$ & $\begin{array}{l}\text { the ratio between total debt and own capital expressed as a } \\
\text { decimal number using a ratio scale }\end{array}$ \\
\hline Debt Cost & $B I U T$ & $\begin{array}{l}\text { company interest expense which is stated in the form of } \\
\text { billions of rupiah using a ratio scale }\end{array}$ \\
\hline $\begin{array}{l}\text { Dividend } \\
\text { Policy }\end{array}$ & $D I V$ & $\begin{array}{l}\text { dividend payout ratio is expressed in percentage (\%) using a } \\
\text { ratio scale }\end{array}$ \\
\hline Profitability & PROFIT & $\begin{array}{l}\text { net profit margin is expressed in percentage }(\%) \text { using a ratio } \\
\text { scale }\end{array}$ \\
\hline Company Size & SIZE & $\begin{array}{l}\text { book value of the company's total assets expressed in billions } \\
\text { of rupiah using a ratio scale }\end{array}$ \\
\hline Business Risk & RISK & $\begin{array}{l}\text { standard deviation of the comparison between DEBIT and } \\
\text { sales measured during the last } 3 \text { years, expressed in } \\
\text { percentage (\%) using a ratio scale. }\end{array}$ \\
\hline $\begin{array}{l}\text { Growth } \\
\text { Company }\end{array}$ & GROWTH & $\begin{array}{l}\text { changes in the company's total assets in the previous year } \\
\text { period ( } t \text { - } 1) \text { to the current year period }(t) \text { which is expressed } \\
\text { in decimal form using a ratio scale }\end{array}$ \\
\hline
\end{tabular}

Source: Data processed, 2020

The analytical method used in this study is multiple linear regression analysis. In general, the multiple linear regression model in this study is divided into three models, namely: (1) a regression model in the coal sub-sector, (2) a regression model in the non-coal sub-sector, (3) a combined regression model between the coal and non-coal subsectors. . Each of these regression models in general has the following equation:

$$
D E R_{i t}=b_{0}-b_{1} B_{I U T} T_{i t}+b_{2} D_{I V}-b_{3} P_{R O F I T}+b_{4} S_{I Z E_{i t}}-b_{5} R I S K_{i t}+b_{6} G_{R O W T H_{i t}}+e_{i t}
$$

$F$ test and test will be applied to the regression model for the coal and non-coal sub-sectors to assess the significant influence of the independent variables either simultaneously or partially. Classic assumption tests are also carried out to ensure that the two regression models are BLUE (Best Linear Un] Estimator). To identify the difference in the determinant influence of capital structure in the coal and non-coal sub-sectors, the Chow test was applied in this study. A combined regression model is required in Chow's test to calculate the restricted residual sum of square (RSSr) value. The steps in carrying out the Chow test include the following (Ghozali, 2006: 132):

1. Calculating the residual sum of square in the regression model for the coal sub sector and the regression model for the non-coal sub sector, hereinafter referred to as RSS1 and RSS2, respectively.

2. Calculating the restricted residual sum of square obtained from the combined regression model, here in after referred to as RSSr.

3. Adding RSS1 and RSS2 to obtain the unrestricted residual sum of square (RSSur).

4. Calculate the F-count value with the following formula:

$$
F=\frac{[R S S r-R S S u r] / k}{R S S u r /(n 1+n 2-2 k)}
$$

5. Compare values F-count with the F-table: 
a. If F-count $>$ F-table, it can be concluded that there is a difference in the influence of BIUT, DIV, PROFIT, SIZE, RISK, and GROWTH on DER in the coal and non-coal sub-sectors.

b. If F-count $<F$-table, it can be concluded that there is no difference in the effect of BIUT, DIV, PROFIT, SIZE, RISK, and GROWTH on DER in the coal and non-coal sub-sectors.

\section{RESULTS AND DISCUSSIONS}

\section{Results of Multiple Linear Regression Analysis}

Before multiple linear regression analysis was performed, all observational data were transformed into a z-score. The Z-score is a data value that has a mean of zero with a standard deviation of one. This was done because there were several observational data that were not normally distributed. The results of multiple linear regression analysis, where all observational data are converted in the form of zscore, it shows that the regression model in the non-coal sub-sector is experiencing heteroscedasticity problems. To overcome the heteroscedasticity problem, the Weight Least Square (WLS) method was applied to the non-coal sub-sector regression model. WLS is a regression model in which all variables are given weighted weight. Details of the results of multiple linear regression analysis in the coal sub-sector and the results of regression analysis using the WLS method in the non-coal subsector are presented as follows:

Table 2. Results of WLS Regression Analysis in Coal and Non Coal Sub-Sector

\begin{tabular}{lcccc}
\hline \multirow{2}{*}{ Variable } & \multicolumn{2}{c}{ Coal Sub-Sector } & \multicolumn{2}{c}{ Non Coal Sub-Sector } \\
\cline { 2 - 5 } & Coefficient & $\boldsymbol{t}_{\text {count }}$ & Coefficient & $\boldsymbol{t}_{\text {count }}$ \\
\hline Constant & 2,189 & $0,000^{t s}$ & 0,158 & $0,722^{\text {ts }}$ \\
\hline BIUT & 0,120 & $0,796^{t s}$ & 0,022 & $1,588^{*}$ \\
\hline DIV & $-0,232$ & $-1,114^{t s}$ & $-0,091$ & $-3,124^{* * *}$ \\
\hline PROFIT & 0,019 & $0,121^{t s}$ & 0,013 & $0,103^{t s}$ \\
\hline SIZE & $-0,033$ & $-0,408^{t s}$ & 0,081 & $3,032^{* * *}$ \\
\hline RISK & 0,019 & $-0,079^{t s}$ & 0,566 & $6,848^{* * *}$ \\
\hline GROWTH & 0,283 & $2,233^{* *}$ & $-0,044$ & $-0,592^{t s}$ \\
\hline \multicolumn{1}{c}{$R^{2}$} & \multicolumn{3}{c}{0,265} \\
\hline \multicolumn{1}{c}{$F_{\text {count }}$} & $1,449^{t s}$ & \multicolumn{2}{c}{$21,493^{* * *}$} \\
\hline
\end{tabular}

Information: $*=$ significant on $\alpha=10 \% ; * *=$ significant on $\alpha=5 \%$; *** significant on $\alpha=$ $1 \%$; ts = insignificant

$F$ test results show that simultaneously, the cost of debt, business risk, company size, company growth, dividend policy, and profitability do not have a significant effect on the capital structure of the coal sub-sector. However, these factors simultaneously affect the capital structure of the non-coal sub-sector. These results imply that the fundamental factors studied in this study are the main factors affecting the capital structure decisions in the non-coal sub-sector. However, the fundamental factors examined in this study are not the main factors affecting the capital structure decisions for the coal sub-sector. This indicates that the management of the coal mining sub-sector company needs to consider other factors such as external factors, considering that this industrial sub-sector is very sensitive to global economic fluctuations.

The coefficient of determination $\left(R^{2}\right)$ in the coal sub-sector is relatively small, which is only 0.265 or $26.5 \%$. These results indicate that $26.5 \%$ of the DER variation can be explained together by 
variations in BIUT, RISK, SIZE, GROWTH, DIV, and PROFIT while the remaining $73.5 \%$ is explained by residuals, namely other independent variables that are not modeled.

The coefficient of determination $\left(R^{2}\right)$ in the non-coal sub-sector is relatively large, amounting to 0.772 or $77.2 \%$. These results indicate that $77.2 \%$ of the DER variation can be explained jointly by the variation of BIUT, DIV, PROFIT, SIZE, RISK, and GROWTH while the rest (22.8\%) is explained by residuals, namely other independent variables that are not modeled.

The partial test results for the regression model in the coal sub-sector show that only the GROWTH variable has a significant positive effect on DER. Meanwhile, the variables BIUT, DIV, PROFIT, SIZE, and RISK statistically did not have a significant effect on DER. The direction of the positive influence of GROWTH shows that the higher the growth of assets, the higher the use of debt in company funding and vice versa. The direction of this influence is in accordance with the pecking order theory which states that if internal funds are insufficient, the first alternative for external funds to choose is to use debt first rather than issuing new shares. The results of this study are consistent with the results of research by Lestari (2015), Jubaedah and Fadila (2018), Prihasti (2018), and Setiawati (2018). However, this is not consistent with the research results of Zulvia (2016), Nugroho and Harmadi (2018), Astakoni and Utami (2019), and Febriani and Kristanti (2020) which show that the GROWTH variable has a significant negative effect on DER.

The partial test results for the regression model in the non-coal subsector show that BIUT, SIZE, and RISK have a significant positive effect on DER, while DIV has a significant negative effect on DER. While the GROWTH and PROFIT variables are known to have no effect on DER in the noncoal sub-sector.

The direction of BIUT's positive influence indicates that the company continues to use high debt even though it has to bear very large financial obligations. This means that companies tend to carry out debt financing to meet their funding needs. This result contradicts the trade off theory which predicts that financial leverage will decrease in line with the cost of debt.

The direction of the positive influence of RISK shows that the higher the business risk that must be faced, the company actually increases its debt in funding. These results indicate that the non-coal sub-sector companies have a very high profit growth opportunity. This condition results in the company having a large enough capacity to bear the risks arising from the use of higher debt to increase investment and production capacity. This contradicts the pecking order theory which states that companies choose their funding sources according to the level of risk that must be faced. The results of this study are inconsistent with the results of research by Lestari (2015) and Zulvia (2016) which show that the RISK variable has a significant negative effect on DER. As well as the research results of Ardiansyah and Srimindarti (2018), Astakoni and Utami (2019), and Febriani and Kristanti (2020) which show that the RISK variable has no significant effect on DER.

The direction of the positive influence of SIZE shows that the larger the size of the company, the greater the debt used by the company and vice versa. The size of the company greatly influences the decision to use debt in the capital structure, especially in relation to the ability to obtain loans. Large companies tend to use debt as an alternative funding because large companies are more diversified and easier to access the capital market. This is because large companies are relatively more stable and able to generate higher profits than small companies. The results of this study are consistent with the results of research by Yushinta and Suryandari (2016), Wardita and Astakoni (2018), Asteria (2018), Nugroho and Harmadi (2018), Astakoni and Utami (2019), and Salmah and Elmeira (2019). However, this is not consistent with the research results of Lestari (2015) and Febriani and Kristanti (2020) which show that the SIZE variable has a significant negative effect on DER. As well as the 
research results of Sansoethan and Suryono (2016), Guna and Sampurno (2018), Jubaedah and Fadila (2018), Prihasti (2018), and Setiawati (2018) which show the SIZE variable has no significant effect on DER.

The direction of the negative influence of DIV shows that the bigger the company distributes dividends, the smaller the debt used by the company and vice versa. Dividend distribution will improve the welfare of investors or shareholders. This condition will lead to positive market expectations of the company's shares so that shareholders or investors will invest more of their funds into the company. This makes it easier for companies to carry out equity financing through the issuance of capital securities rather than using debt. Theoretically, this contradicts the pecking order theory which states that companies prefer external funding in the form of debt first rather than issuing new shares. The results of this study are inconsistent with the results of Prihasti's (2018) research which shows that the DIV variable has no significant effect on DER.

\section{Chow Test Results}

In the Chow test, a combined regression model between coal and non-coal subsectors is required to calculate the restricted residual sum of square (RSSr). The following are the results of the analysis of the combined regression model:

Table 3. Results of Combined Regression Analysis

\begin{tabular}{|c|c|c|}
\hline Variable & Coefficient & $t_{\text {count }}$ \\
\hline Constant & $-0,137$ & $-1,712^{t s}$ \\
\hline$B I U T$ & 0,042 & $0,181^{t s}$ \\
\hline$D I V$ & $-0,029$ & $-2,618^{* * *}$ \\
\hline PROFIT & $-0,067$ & $-0,174^{t s}$ \\
\hline SIZE & $-0,031$ & $-0,495^{t s}$ \\
\hline RISK & 0,265 & $2,610^{* *}$ \\
\hline GROWTH & 0,019 & $1,112^{t s}$ \\
\hline$R^{2}$ & \multicolumn{2}{|c|}{0,345} \\
\hline$F_{\text {count }}$ & \multicolumn{2}{|c|}{$9,417^{* * *}$} \\
\hline
\end{tabular}

Information: $* *=$ significant on $\alpha=5 \% ; * * *=$ significant on $\alpha=1 \%$; ts $=$ insignificant

After the combined regression model between coal and non-coal subsectors is obtained, the restricted residual sum of square (RSSr) can be calculated. The residual sum of square value in each subsector can be seen in the following table:

Table 4. Summary of Residual Sum of Square in Each Sub-sector

\begin{tabular}{lc}
\hline \multicolumn{1}{c}{ Sub-Sector } & Residual Sum of Square \\
\hline Coal & 70,130 \\
\hline Non-coal & 19,256 \\
\hline Combined & 105,329 \\
\hline
\end{tabular}

Source: Data processed, 2020 
Based on the residual sum of square data above, a Chow test was performed to assess the differences in the effect of BIUT, DIV, PROFIT, SIZE, RISK, and GROWTH on DER in the coal and non-coal sub-sectors by calculating the $F$ value through the following formula:

$$
\begin{aligned}
& F=\frac{[105,329-(70,130+19,256)] / 6}{(70,130+19,256) /(79+66-12)} \\
& F=\frac{2,657}{0,672} \\
& F=3,954
\end{aligned}
$$

Based on the results of the above calculations, the Fcount value is obtained at 3.954. After the Fcount value is obtained, the next step to take is to compare the Fcount value with the Ftable value. Through the F table with $d f 1(k)=6, d f 2(n 1+n 2-2 k)=133$ and a significance level of $\alpha=0.05$, the Ftable value is 2.14. Because the value of Fcount> Ftable, it can be concluded that there are differences in the influence of BIUT, DIV, PROFIT, SIZE, RISK, and GROWTH on DER in the coal and non-coal sub-sectors. The difference in the determinant influence of capital structure in the coal and non-coal sub-sectors can be examined from two aspects, namely the partial influence of the determinant variable of capital structure in the regression model for the coal and non-coal subsectors, and based on the characteristics of the two industrial subsectors.

Based on the results of regression analysis on the coal and non-coal subsectors as shown in Equations 1 and 2, it shows that several determinants of capital structure have an inconsistent effect on the debt ratio. The inconsistency of this influence can be interpreted as two things. First, the determinants of the same capital structure can have a significant effect on the debt ratio in the coal sub-sector, while in the non-coal sub-sector it has no significant effect on the debt ratio or vice versa. In the regression model for the coal sub-sector as shown in Equation 1, the variable cost of debt, business risk, company size, and dividend policy is known to have no significant effect on the debt ratio. However, in the regression model for the non-coal sub-sector as stated in Equation 2, these four variables have a significant effect on the debt ratio. Second, the determinant of the same capital structure can have a positive influence on the debt ratio in the coal sub-sector, while in the non-coal sub-sector it has a negative influence on the debt ratio or vice versa. In the regression model for the coal sub-sector as seen in Equation 1, the business risk variables and company size are known to have a negative effect on the debt ratio, while company growth has a positive effect on the debt ratio. However, in the regression equation for the non-coal sub-sector as stated in Equation 2, business risk and company size have a positive influence on the debt ratio, while company growth has a negative effect on the debt ratio.

Based on their characteristics, the coal and non-coal sub-sectors have different characteristics, especially in relation to the level of risk they have to bear. The coal sub-sector is known to have a greater level of risk than the non-coal sub-sector in carrying out its operations. As stated by Ginting (2010), the coal sub-sector has the lowest exploration success rate among other mining sub-sectors (between 2\% - 5\%), and is classified as the slowest producing activity (8-10 years before reaching the exploitation stage). In fact, the exploration and exploitation stages carried out are very costly. This results in the coal sub-sector having to bear much greater financial risk than other mining subsectors. Under such conditions, the factors considered by the coal sub-sector in determining its capital structure decisions are certainly different from those considered by the non-coal sub-sector. 


\section{CONCLUSION}

Based on the results of data analysis and discussion, some conclusions in this study include: the simultaneous test results show that the fundamental factors studied in this study are not the main factors affecting the capital structure decisions in the coal sub-sector. However, the six fundamental factors examined in this study, namely the cost of debt, dividend policy, profitability, company size, business risk, and company growth are the main factors that influence capital structure decisions in the non-coal sub-sector. Partially, the six fundamental factors have varying effects. The results of the analysis show that there is an inconsistency in the influence of the determinants of capital structure in the coal and non-coal subsectors. In the coal sub-sector, only company growth has a significant effect. Meanwhile, the cost of debt, business risk, company size, dividend policy and profitability do not statistically have a significant effect on the debt ratio. In the non-coal sub-sector, it is known that the cost of debt, business risk, company size, and dividend policy have a significant effect on the debt ratio. Meanwhile, the profitability and growth of the company do not have a statistically significant effect on the debt ratio. The Chow test results show that there are differences in the influence of the six fundamental factors on capital structure decisions in the coal and non-coal sub-sectors. The difference in the determinant influence of the capital structure can be examined from two aspects. First, the difference in these effects can be assessed from the inconsistency of the influence of each determinant variable of capital structure on the debt ratio in the coal and non-coal sub-sectors. Second, this difference in influence is because the two industrial subsectors have different characteristics, where the coal sub-sector must bear a greater risk than the non-coal sub-sector in carrying out its operations. In other words, capital structure decisions are influenced by the characteristics of each subsector.

\section{LIMITATION AND STUDY FORWARD}

Mining companies, both companies sub-sector coal and non-coal should have to continue to examine the company's internal conditions without ignoring external factors in determining an alternative source of funding. In addition, the company also must be careful in deciding the amount of debt used in financing by considering the financial obligations and the risks they incur. It is based on research which shows that companies that have debt costs and business risks are high, it will increase the debt. This study still has limitations, including the results of different tests or structural stability with the Chow test, which can only assess the stability of the structure or parameters in the regression model without informing how big the changes or differences are. Future researchers are expected to be able to conduct a deeper study of the differences in the influence of determinants of capital structure in various industrial sectors which are more complex with better analytical methods.

\section{REFERENCES}

APBI-ICMA. (2020). Challenges in meeting the 2020 DMO amid the covid-19 pandemic. Accessible via http://www.apbi-icma.org/news/3111/tantangan-dalam-memenuhi-dmo-2020-di-tengahpandemi-covid-19 on September 01, 2020.

Ardiansyah, F. D. S., \& Srimindarti, C. (2018). Determination of the capital structure of property and real estate companies listed on the IDX for the period 2012-2016. Proceedings SENDI_U. Universitas Stikubank.

Astakoni, M. P., \& Utami, N. M. S. (2019). Determinants of the company's capital structure (study of the cosmetics \& household goods sub-sector manufacturing companies listed on the Indonesia Stock Exchange for the period 2010-2016). ECONOMIC WACANA (Journal of Economics, Business and Accounting). 18 (1), 1-16.

Asteria, B. (2018). Determinants of the capital structure factors of mining companies listed on the Indonesia Stock Exchange. Dewantara Management, 2(1), 1-15. 
Brigham, E. F. \& J. F. Houston. (2011). Financial Management. Eleven Edision. South Western. Thomson. Translate A. A. Yulianto. 2011. Fundamentals of Financial Management. Eleventh Edition. Four Salemba. Jakarta.

Brealey, R. A., Myers. S. C., \& Marcus, A. J. (2008). Basics of Corporate Financial Management. Second Volume. Edition Five. Erlangga. Jakarta.

Febriani, A. D., \& Kristanti, F. T. (2020). Determinants of the capital structure of infrastructure, utility and transportation companies. E-Journal of Economics and Business, Udayana University, 9, 275-302.

Febrianty, R. K., Novianti, T., \& Hardiyanto, A. T. (2020). Analysis of the determinants of the capital structure of the telecommunications industry in Indonesia. Journal of Business and Management Applications (JABM), 6(1), 169-169.

Ghozali, Imam. (2006). Multivariate analysis application with SPSS. Semarang: Diponegoro University Publishing Agency.

Ginting, Daulat. (2010). Coal management policies and prospects in Indonesia. Geological Resources Bulletin, 5 (1).

Gitman, Lawrence J. (2006) Principle of managerial finance, Eleventh Edition. Boston: Pearson Addison-Wesley.

Guna, M. A., \& Sampurno, R. D. (2018). Analysis of the factors affecting capital structure (case study of food and beverage companies listed on the IDX for the period 2012-2016). Diponegoro Journal of Management, 7(2), 236-247.

Hanafi, M. M. \& A. Halim. (2012). Financial Statement Analysis. Third Edition. UPP YKPN School of Management. Yogyakarta.

Jubaedah, J., \& Fadila, A. (2018). Determinants of capital structure (studies on manufacturing companies). Journal of MEBIS (Management and Business), 3 (2), 1-13.

Keown, Arthur J., David F Scott Jr, John D Martin, J William Petty. (2000). Basics of financial management volume 2. Translation by Chaerul Djakman. Jakarta: Four Salemba.

Lestari, S. (2015). Determinants of capital structure in the perspective of pecking order theory and agency theory (empirical study of manufacturing companies listed on the IDX in 2010-2013). Forum for Accounting Research, 3 (1).

Myers, Stewart C. (2001). Capital Structure. The Journal of Economic Perspectives. American Economic Association Vol. 15, No. 2, Hlm. 81-102.

Moeljadi. (2006). Financial management with quantitative and qualitative approaches volume 1. Malang: Bayumedia.

Musabbihan, N. A., \& Purnawati, N. K. (2018). Effect of profitability and dividend policy on firm value with capital structure as mediator. E-Jurnal Manajemen, 7(4), 1979-2009.

Nugroho, B. H., \& Harmadi, H. A. (2018). Determinants of the company's capital structure in Southeast Asian countries. Business Strategy Journal, 22(2), 144-163.

Prihasti, P. R. (2018). Factors affecting the capital structure of manufacturing companies on the Indonesia Stock Exchange. Journal of Accounting Science and Research (JIRA), 7(2).

Putra, K. A. A., \& Diantini, N. N. A. (2016). Determination of the capital structure of automotive companies on the Indonesia Stock Exchange. Journal of Economics and Tourism, 10(2), 12-21.

Salmah, N. N. A., \& Ermeila, S. (2019). Determinants of the capital structure of the building construction sub-sector companies on the Indonesia Stock Exchange. Economical: Journal of Economics and Business, 3(2), 137-145.

Sansoethan, D. K., \& Suryono, B. (2016). Factors that affect the capital structure of food and beverage companies. Journal of Accounting Science and Research (JIRA), 5(1).

Sartono, R. A. (2001). Financial Management Theory and Applications. 4th Edition BPFE. Yogyakarta.

Setiawati, P. S. (2018). Determinants of capital structure in the consumer goods industry sector. Journal of Accounting Science and Research (JIRA), 7(3). 
Sundjaja, Ridwan S., \& Berlian, Inge. (2003). Financial Management 2, Fourth Edition. Jakarta: Literata Lintas Media.

Wahyuni, I., \& Ardini, L. (2017). The influence of growth opportunity, profitability and dividend policy on capital structure. Journal of Accounting Science and Research (JIRA), 6(4).

Wardita, W., \& Astakoni, M. P. (2018). Profitability, company growth and company size are determinants of capital structure. KRISNA: Collection of Accounting Research,9(2), 20-32.

Yusintha, P., \& Suryandari, E. (2016). Analysis of the factors that affect the capital structure. Journal of Accounting and Investment, 11(2), 179-188.

Zulvia, Y. (2016). Determinants of capital structure in manufacturing companies on the Indonesia Stock Exchange. Journal of Business Management Studies, 5(1). 